\title{
Al-Qur'an Transliteration According to Muallaf at Annaba Center Indonesia
}

\author{
Tety Juwariyah $^{1}$, Ulfah Nur Azizah ${ }^{2}$, Yusuf Rahman ${ }^{3}$ \\ \{tettyjuwairiyah@gmail.com¹, nurazizah916@gmail.com² ${ }^{2}$ yusufrahman@uinjkt.ac.id ${ }^{3}$ \} \\ Graduate School of UIN Syarif Hidayatullah Jakarta ${ }^{123}$
}

\begin{abstract}
Transliteration of Al-Qur'an among converts is deemed necessary, In practice, users do not really understand some of the symbols in the transliteration contained in the Mushaf. This study aims to find out how the views of the santri, to know the impact of the transliteration of the Al-Qur'an for them. This research is a field research with qualitative research type. The subjects of this study were the students at the Annaba Center Indonesia Foundation for Islamic Boarding School Muallaf Development. One of which is the santri, who are users of the Al-Qur'an Transliteration from among converts get the impact of studying the Al-Qur'an Transliteration, by participating in the recitation of Al-Qur'an reading deposits, it is known that transliteration can spoil the user if it is not accompanied by learning Al-Qur'an reading. -Intensive Quran, users are also felt to be minimal in reading information about transliteration and have not tried their best to find out and learn more about what and how transliteration is.
\end{abstract}

Keywords: Transliteration, Muallaf, Mushaf.

\section{Introduction}

Al-Qur'an is a holy book that must be read, its meaning is implemented and practiced for Muslims in everyday life. This book that was revealed to the Prophet Muhammad uses Arabic, according to the language used by the Prophet Muhammad, in the words of Allah SWT:

"Indeed, We sent it down in the form of Al-Qur'an in Arabic so that you will understand." (Q.S Yusuf / 12: 2).[1]

In practice, not all Muslims are able to read the Al-Qur'an in Arabic script. In the Daily Republika, quoting from Wildan, the Academic Leader of the Al-Qur'an, stated that the number of Indonesians who cannot read the Qur'an is around $60 \%$. This means that only $40 \%$ of Muslims in Indonesia can read the Al-Qur'an. From 40\%, only 20\% can read it properly.[2] Indonesia is a country with the largest Muslim population in the world and a Muslim is required to be on time and pray in Arabic. Even though the Indonesian population is Muslim, not all of them can read the Al-Qur'an which is written in Arabic.[3] This data at least gives an overview of the condition of the Indonesian Muslim community in reading the Al-Quran. To help people who cannot read Arabic letters, it is necessary to convert Arabic letters to Latin letters in Indonesian. From here then came the need for the Al-Qur'an transliterated Latin, as a way out to solve the problem of reading the Al-Qur'an. Latin Arabic transliteration is a method or approach used so that Arabic and written language can be represented spoken in Latin script. Transliteration itself is used for various purposes, such as titles and names of people, 
cataloging, and Arabic. lessons. Transliteration is also called in the Big Indonesian Dictionary, as the copying and replacement of one alphabetical letter to another.[4]

The government has issued a decree for the Minister of Religion and the Minister of Culture or what is often called the "Joint Ministerial Decree" hereinafter referred to as SKB2M, No. 158/1987-No. 0543 / u / 1987 on Latin Arabic Transliteration.[5] Then in 2007 the Lajnah Pentashihan Mushaf Al-Qur'an Agency for Research and Development and Education and Training of the Ministry of Religion of the Republic of Indonesia published the Tajweed Transliteration Al-Qur'an Manual as a development of the SKB2M. The Tajweed Transliteration Guidelines are used as a reference for publishers who will publish the transliterated Al-Qur'an. The pentashihan data in the Pentashihan Mushaf Al-Qur'an Lajnah shows that in 2015 the transliteration of the Al-Qur'an manuscript with various variants was submitted by many publishers for ditashih. There are various transliteration models, all of which have their own place in society. This fact reinforces the assumption that many people use Al-Qur'an Transliteration because they cannot read Arabic characters.[6]

Straightening the spelling of the Arabic loanwords as well as the Arabic-Latin transliteration guidelines is very urgent to do. Because, at this time there are so many guidebooks to read the Al-Qur'an, worship guides and prayers that use transliteration, namely writing Arabic words (pronunciation) in Latin letters. The goal is to make it easier for ordinary people to learn to read the Qur'an by themselves. The problem lies in the practice of transliteration. To read the Al-Qur'an or recite Arabic recitations must require teacher guidance. Without teacher guidance, and only relying on transliteration guides, it is feared that it will result in incorrect pronunciation. Ideally, this transliteration should be able to guide the reader to pronounce lafadz-lafadz Al-Qur'an correctly. Regarding transliteration teaching, there are two different views. The first group argues that transliteration is a symbol of Arabic letters only. The second group consists of those who consider transliteration not just symbols, but letters that have been standardized according to Enhanced Spelling.[7]

\section{Discussion}

Transliteration comes from English "transliteration", which means sound symbols, phonemes, or words in the writing system, or symbols that are determined according to the rules of the language.[8] From this understanding, it can be seen that transliteration is related to sound symbols and writing systems.

In the Fandom House Webster's College Dictionary, transliteration is taken from the verb "transliterate" which means to change (letters, words, etc.) into the corresponding characters of another alphabet or language.[9] In Webster's New Twentieth Century Dictionary Of The English Language Unabrigde, transliteration is defined as to write or spell (words, etc) in the alphabetical characters of another language that represents the same sound or sounds.[10] In this sense, transliteration can be interpreted as writing and pronouncing foreign letter characters in the form of symbols that have the same sound.

The government has issued SKB of the Minister of Religion and the Minister of Education and Culture (often referred to as the "Joint Ministerial Decree" / SKB2M), No. 158 / 1987- No. 0543 b / u / 1987 on Arabic-Latin transliteration. Then in 2007 the Lajnah Pentashihhan Mushaf Al-Qur'an, Research and Development and Training Agency of the Ministry of Religion of the Republic of Indonesia published the Tajweed Transliteration Al- 
Qur'an Manual as a development of the SKB2M. The Tajweed Transliteration Guidelines are used as a reference for publishers who will publish the transliterated Al-Qur'an.[6]

When viewed in the field, transliteration based on SKB2M has been widely used, especially by government institutions, public and private educational institutions, and especially the Lajnah Pentashih Mushaf Al-Qur'an of the Indonesian Ministry of Religion. This transliteration is not specifically intended to transcribe the Al-Qur'an but to transliterate Arabic script in general into Latin (Indonesian) script for academic purposes and so on.[11] According to Ahmad Musaddad, quoting Ismail Raji al-Faruqi as saying: The purpose of translating the Al-Qur'an letters is to bring people who are less able to read Arabic letters to the actual pronunciation of the Al-Qur'an text. Regarding this, Isma'il Raji al-Faruqi said, "The Latin alphabet transliteration of the Qur'anic passage is not the holy al-Qur'an al-Karim, but a means to reaching and understanding it." [6] Arabic -Latin from the verses of the Koran is not the holy Qur'an itself. However, it is only a means of reaching and understanding it.

This research is a type of field research with a mixed approach, namely qualitative and quantitative. A qualitative approach is shown to understand social phenomena from the perspective of the participants. The quantitative approach is shown to study large and small populations by selecting and examining selected samples from the population to find the relative identity,[12] distribution, and interrelation of the sociological and psychological variables. [13] This research is also supported by a research library.

The scholars are very careful in this matter, because they try to always protect the Qur'an and really care about it, so that the Qur'an can be protected both in terms of reciting and writing. He can be read as when he was sent down, namely in the time of the Prophet Muhammad, both regarding the hum, the length and the short, the harakat-harakat, the breadfruit, and so on.[14] There were differences of opinion among scholars regarding the writing of the Al-Quran for non-Arab residents using this Latin script or transliteration. AlImam Al-Marginani, who once wrote the book Al-Hidayah, said "It is forbidden to write the Mushaf in Persian. And this has become the agreement of the scholars. "[15]

Abu 'Amr al-Dani, quoting the words of al-Imam Malik, when asked about the ability to violate the letters wa and alif in the Mushaf, he said "no". [16] In another narration it states: "... Malik was asked: what do you think about the person being asked to write the Mushaf at this time. Did he write it as the hijaiyah letters that are circulating today. He replied: I have no opinion about that. However, he must write it as the initial writing.[16]. than Arabic letters so that non-Arabs can read it? " he replied, "It is the agreement of the scholars, that it is haram."[15] Whereas scholars who allow the opinion that the writing of the Koran in nonArabic or transliteration is not tauqifi from the Prophet, but only one way of writing that is approved and accepted by the people well, so it becomes a necessity that must be used as a reference and should not be violated. Among these scholars are Shaykh Izuddin ibn Abdussalām, Badruddīn Muhammad ibn 'Abdu al-Lāh al-Zarkasȳi and others. Al-Zakarsȳ̄ said that following writing with one model only applies to the early generations, because science develops along with the times and now it is feared that there will be a misunderstanding of the Al-Qur'an among the common people.[17]

The Annaba Center Indonesia Muallaf Development Foundation is the first Muslim Islamic boarding school established in Indonesia built in 2008 on an area of 1,200 meters which is the waqf of the Muslims, starting from the male training dormitory located on J1. Cenderawasih IV, No. 1 Rt 02 Rw 03 Kel. Sawah Baru, Kec. Ciputat. Then after that in 2014 a special hostel for girls was built and it was inaugurated in 2016. [18] The background for the establishment of the Annaba Center Indonesia Foundation stems from the personal experience of Ust Syamsul Arifin Nababan or commonly called Ust Nababan. Ustadz Nababan is a ustadz 
with a convert to Islam who feels concerned and is called to save the faith of the converts because most of the converts feel lost their way when they first converted to Islam. They do not get a touch of religious formation after vowing to say 2 sentences of the shahada and then get a certificate of being Muslim. In learning the Qur'an, students or students have different study times or time to read the Qur'an. However, most of the informants read the Al-Qur'an after the Fajr prayer because there was a reading deposit that required them to read the Qur'an after the Fajr prayer. In the agreement or commitment set by the supervisor and leader of the Islamic Boarding School for Muallaf Development, the Annnaba Center Indonesia Foundation Ust. Syamsul Arifin Nababan said that every convert who wants to become a santri in Annaba is obliged to be able to read the Al-Qur'an within 1 month, [18] however the author found that some students can only read the Al-Qur'an for more than 1 month. The author also found that all those who reach the target of 1 month can read the Koran and spend time reading the Qur'an apart from when they are deposited or after dawn prayers, they also routinely read the Koran after fardhu prayer., after the sunnah prayer, even in his spare time at school. In contrast to those who did not reach the target for 1 month, they read the Koran only when the deposits were even the authors also found that deposits were mandatory for students, but in fact not all students followed the reading deposits to ustadzah or Al-Qur'an teachers. 'an and after being traced and conducting more in-depth interviews that those who are considered to have reached the target of 1 month in reading the Qur'an are not yet fully fluent in reading the Qur'an, therefore some of them admit that they are still using the Al-Qur'an. Transliteration Qur'an in order to smooth or just ensure their reading when reading the Qur'an. Based on the writer's findings, the time spent by the students to read the Al-Qur'an is very influential on their achievement of fluency in reading the Al-Qur'an.

As discussed in the previous chapter, transliteration can be interpreted as writing and pronouncing foreign letter characters in the form of symbols that have the same sound. Meanwhile,[10] according to Kridalaksana, transliteration is "the replacement of letter by letter from one alphabet to another (often separated from the actual pronunciation): for example, Abd al-Rauf's writing is a transliteration, which is different from Abdurrauf's which is a transcript and according to the pronunciation.[19] From the results of the analysis, the author obtained an understanding of the definition of transliteration in the Koran according to the students at the Islamic Boarding School for Muallaf Development at the Annaba Center Indonesia Foundation, which is divided into two groups of understanding, namely transliteration of the Qur'an, Arabic-Latin (Indonesian) and transliteration of Al. -Qur'an as a tool in reading the Koran. Of the 18 informants, 11 of them understood that the transliteration of the Al-Qur'an was Arabic-Latin (in Indonesian), while 7 of them understood that the transliteration of the Al-Qur'an was a tool for reading the Al-Qur'an.

According to the students at the Annaba Center Indonesian Islamic Boarding School, the transliteration view of the Al-Qur'an is divided into 2 groups of views. There are those who think that transliteration of the Al-Quran is easy and others see that transliteration of the AlQuran is a way to help read the Al-Qur'an. Of the 18 informants who saw the transliteration of the Al-Qur'an easier, there were 8 people and 10 others saw transliteration of the Al-Qur'an as a way to help read the Al-Qur'an. According to the author's investigation of the students at the Annaba Center Indonesia Islamic Boarding School for Converts who have a convert to Islam, one of the reasons for deciding to convert to Islam is because the language of the Qur'an is so interesting to hear that has an impact on peace of mind and soul.[20] This also became one of the reasons for the interest of the students to study the Qur'an more deeply. 


\subsection{Transliterated Al-Qur'an Mushaf Profile}

The author examined 3 Mushaf Al-Qur'an Transliteration used by students at the Islamic Boarding School for Muallaf Annaba Center Indonesia. Here the author provides a brief explanation, in order to find out the information on each Mushaf studied.

Mushaf Al-Qur'an Transliteration Per Word and Translation Per Word (AT-THAYYIB) 2011.

This manuscript is equipped with transliteration per word and translation per word, the transliteration used is the Arabic-Latin transliteration guideline of the joint decision of the Minister of Religion and the Minister of P and K No: 158 of 1987- Number: $0543 \mathrm{~b} / \mathrm{u} / 1987$ the purpose of its publication is expected " The presence of Mushaf At-Thayyib can multiply the rewards of the readers because it leads the reader to be more precise and truer in reading the Qur'an and guides the reader to be able to understand all the words in the Qur'an that are read.[21]

\subsection{Mushaf Al-Qur'an Al-Hadi Latin Mushaf 2015}

This manuscript is equipped with a standard Latin transliteration of the Koran of the Ministry of Religion of the Republic of Indonesia per word, a translation of the version of the Ministry of Religion of the Republic of Indonesia which is equipped with the title and subtitles of each theme in translation, asbabun nuzul, translation per word, as well as recitation and description of how to read on each page. The purpose of publishing this manuscript according to the information contained in the "Preface" of the Mushaf is "to be more able to provide colors in the publication of the Koran so that every Muslim in Indonesia in particular and the whole world in general loves, owns, and shares knowledge. which we have learned by examining the path above the Qur'an and the Sunnah. "[22]

3. Mushaf Al-Qur'an Tajweed Color Transliteration Per Verse Translated Per Verse (AlMunawwar) 2015

This manuscript is equipped with Tajweed Color, transliteration per verse, translation per verse. The purpose of publishing this manuscript according to the information contained in the "Foreword" of the Mushaf is "so that Indonesian Muslims can find it easier and more motivated to continue learning, teaching and practicing the Al-Qur'an.[23]

Time to Read Al-Qur'an Santri Annaba Center

In the agreement or commitment set by the supervisor and leader of the Islamic Boarding School for Muallaf Development, the Annnaba Center Indonesia Foundation Ust. Syamsul Arifin Nababan that every convert who wants to become a santri in Annaba is obliged to be able to read the Al-Qur'an within 1 month.[18]

Here the author found that there were several students who had only been able to read the Al-Qur'an for more than 1 month. The author also found that all those who reach the target of 1 month can read the Koran and spend time reading the Qur'an apart from when they are deposited or after dawn prayers, they also routinely read the Koran after fardhu prayer. , after the sunnah prayer, even in his spare time at school.

In contrast to those who did not reach the target for 1 month, they read the Koran only when the deposits were even the authors also found that deposits were mandatory for students, but in fact not all students followed the reading deposits to ustadzah or Al-Qur'an teachers. 'an and after being traced and conducting more in-depth interviews that those who are considered to have reached the target of 1 month in reading the Qur'an are not yet fully fluent in reading the Qur'an. 
Therefore they admit that they still use the Al-Qur'an Transliteration in order to streamline or just confirm their reading when reading the Al-Qur'an.

Tabel 1. List time of reading holy Al-Qur'an

\begin{tabular}{|c|l|c|}
\hline No & \multicolumn{1}{|c|}{ Time of reading holy Al-Qur'an } & Number of Mentions \\
\hline 1 & After Shalat Subuh & 5 \\
\hline 2 & After Shalat Ashar & 1 \\
\hline 3 & After going to school & 1 \\
\hline 4 & Every Friday night & 1 \\
\hline 5 & After shalat fardhu & 1 \\
\hline 6 & When i taking mood & 1 \\
\hline 7 & Five times in a week & \\
\hline
\end{tabular}

Ownership of Al-Qur'an Transliteration

Here the authors present the ownership data of students who have a transliterated AlQur'an from this data, the author calculates the answers to the same interview results and the authors present them in the table below:

Tabel 2. List Ownership of Al-Quran Transliteration

\begin{tabular}{|c|c|c|}
\hline No. & Ownership of Al-Quran Transliteration & Number of Mentions \\
\hline 1 & Private property & 11 \\
\hline 2 & Borrow to Mushalla & 7 \\
\hline 3 & $\begin{array}{c}\text { Borrow to friends, senior, and older } \\
\text { siblings }\end{array}$ & 2 \\
\hline
\end{tabular}

The reason for the interest in converting 
In the following, the author will show a table of various reasons for the interest in converting to the Islamic Boarding School for Muallaf Development of the Annaba Center Indonesia Foundation.

Tabel 3. list Reasons for Interest in Converting

\begin{tabular}{|c|c|c|}
\hline No. & Reasons for Interest in Converting & Number of Mentions \\
\hline 1 & How to dress & 6 \\
\hline 2 & Good morals & 7 \\
\hline 3 & polite & 2 \\
\hline 4 & Good words & 4 \\
\hline 5 & Directed Islamic teaching & 5 \\
\hline 6 & Recitation of the holy Qur'an & 3 \\
\hline 7 & Call to prayer & 1 \\
\hline 8 & Shalawat & 4 \\
\hline 9 & Trinity & 2 \\
\hline 10 & Nyaman & 3 \\
\hline 11 & Comfortable & 2 \\
\hline 12 & Calm and serene & 1 \\
\hline 13 & Takbir sound & \\
\hline
\end{tabular}

Some of the informants interviewed by the writer mentioned that one of the reasons they decided to convert to conversion was through hearing, including the informants from Bandung with the initials Z.A and Amel, these two brothers decided to convert to Islam because of the call to prayer.

"Indeed, for us, my brother and I, Islam is not foreign because our environment is indeed Muslim, such as prayer, fasting, the call to prayer is not foreign to us, but at that time our eyes were still closed so that we didn't feel anything untouched to convert to Islam. At first when I was in college I was hit by family problems, I dropped out of college, my college fell apart and saw my parents' condition was not harmonious anymore, there I felt empty lost my life purpose was messy until the peak I was confused where I was going there I was like losing my trust for some reason I am confused about wanting to complain or pray to whom, but I still believe that God is there, finally I prayed even though at that time I did not know my prayer, I showed God who God was where I prayed asking to be given instructions on what I should do. Then I fell asleep and when I woke up all I heard was the sound of the call to prayer at dawn, somehow my heart was so trembling I believed that it was God's guidance for me and it turned out that what I felt was also felt by my sister Amel. Alhamdulillah Allah's guidance came down for us through the call to prayer. "[24] Unlike the case with Aminah Ashri Hutabarat, an accounting scholar from Padang, West Sumatra, she also received guidance through hearing, namely the chanting of the holy Qur'an and the sound of takbir during Eid al-Fitr which could make her heart and soul vibrate to tears.

Not only are they interested in the melodious chanting of the holy Qur'an verses and the sound of the call to prayer. Another reason they are attracted to Islam is that they hear prayers, as expressed by R.S. after hearing the prayers he feels a calm and serenity of the soul that is different from the songs in general, shalawat is felt like a medicine that can reassure the heart and soul

Author concluded that the students at the Annaba Center Indonesia Islamic Boarding School decided to become converts, one of the factors, namely through hearing through the 
chanting of the holy Al-quran, the sound of the call to prayer, the sound of takbir and prayers. This can thrill their hearts and souls so as to lead them to embrace the teachings of Islam.

Furthermore, it can be through feelings, another factor that can be felt is the feeling of being comfortable, calm, serene, and cool when gathering or seeing Muslims gather or interact. Sakinatuddiniah and her narrative felt this:

"My brother and I were invited by my brother to Riau and there were lots of Muslims there. There is a strange feeling there, how comfortable it is so different from Nias because it is usually locked, right? Then this heart is very happy and comfortable to see that Muslims are different from Christian ones because everything feels peaceful and cool. "[25]

And the last one is behavior. According to the data that the author obtained in this behavior there are four reasons that make these students believe to embrace Islam, namely how to dress, good morals, manners, and regular Islam. As stated by Julia Freista Ribeiro or usually called Sofia, she decided to become a convert because she saw the orderly teachings of Islam, then the way to dress Muslims, especially women who are covered and are obliged to wear a hijab, as well as good speech, is polite to all humans.

Transliteration of Al-Qur'an for Muallaf

According to the students at the Annaba Center Indonesian Islamic Boarding School, the transliteration view of the Al-Qur'an is divided into 2 groups of views. There are those who think that transliteration of the Al-Quran is easy and others see that transliteration of the AlQuran is a way to help read the Al-Qur'an. Of the 18 informants who saw the transliteration of the Al-Qur'an easier, there were 8 people and 10 others saw transliteration of the Al-Qur'an as a way to help read the Al-Qur'an.

One of the reasons for deciding to change religions and then convert to Islam is because the language of the Koran is so interesting to hear that it has an impact on the peace of mind and soul.Here the author presents data on various reasons for my interest in studying the Qur'an from this data. for the answers to the same interview results and the authors present in the table below:

Tabel 4. List Reasons for Interest in Studying the Al-Qur'an

\begin{tabular}{|c|c|c|}
\hline No. & Reasons for Interest in Studying the Al-Qur'an & Number of Mentions \\
\hline 1 & Guidelines for Muslims & 2 \\
\hline 2 & Feel closer to God & 5 \\
\hline 3 & Uniquely different from the previous scriptures & 3 \\
\hline 4 & Make it more calm, comfortable, and serene & 3 \\
\hline 5 & The language is very good & 2 \\
\hline 6 & Heart conditioning & 2 \\
\hline 7 & Solutions to various problems & 1 \\
\hline
\end{tabular}

Efforts to Know Recitation and Memorization of Al-Qur'an

The purpose of reading the Koran varies, one of which is to add provisions for the afterlife, which is different from the opinion of other students who express that they feel reading the Koran is an obligation for him because the Qur'an gives a calm impact as well. gain knowledge through translation of the Qur'an. 
In the following, the writer will present the data regarding the reasons for the students to learn recitation / tahsin Al-Qur'an. The data below the authors get from calculating the answers to the same interview results and the authors present them in the table below:

Tabel 5. List Reasons for Studying Tajweed / Tahsin

\begin{tabular}{|c|c|c|}
\hline No & Reasons for Studying Tajweed / Tahsin & Number of Mentions \\
\hline 1 & Correction of redain Qur'an & 13 \\
\hline 2 & Sharpening the tongue accordin to the lawof tajweed & 3 \\
\hline 3 & Know the rules of reading the Qur'an & 2 \\
\hline
\end{tabular}

According to the data that the author obtained, the majority of the reasons for the students to learn to learn recitation / tahsin are to improve the reading and in part, namely to sharpen the tongue so that the reading is in accordance with the law of recitation and to know the principles of the science of recitation.

Recitation of Al-Qur'an Reading Deposit

In the process of depositing the readings, every morning recitation on Monday to Thursday the students at the Islamic Boarding School for Muallaf Annaba Center Indonesia read their respective Al-Qur'an first, then the reading they have read is sent to the ustz. The students are also free to want to read around the mushalla or outside, for example someone reads in front of the mosque, in the gazebo or in their respective rooms. reading the Koran, 3. Benefits of recitation.

Problems and Solutions of Al-Qur'an Transliteration

1. Problematic Users of Al-Qur'an Transliteration

From the data the author obtained, the students at the Annaba Center Indonesian Islamic Boarding School had difficulties when faced with Al-Qur'an Transliteration. The difficulties faced are various, most of the difficulties are confusion when pronouncing letters that have no equivalent such as the letters ص ص ص which according to the old transliteration were written sh and dl or in SKB2M transliteration written with ș and ḍ.

As according to Siti Hajar, he had difficulty reading the Al-Qur'an Transliteration apart from the letters that did not match the pronunciation he was also confused about how long the mad he was reading.

"Sometimes there are obstacles too, but not really because you have a cleric as a companion. Maybe if not accompanied, you can get confused or even misread, for example, how long is the mad, if there is a companion or teacher, we can ask questions, then for example the letter reads the Latin and the writing is different but by listening to the murattal too so know how to read it, while looking at the transliteration or matching it to Arabic while listening to the teacher recitation / murotal. ',[26]

In contrast to Graciella Victoria Safira or commonly called Ciella, she revealed that the Al-Qur'an Transliteration can be a long way for its users because Ciella feels this way. Here's the expression:

"It can be a pleasure to be spoiled if I read the Latin one because I'm used to it and connects when reading it. Right, there are difficulties in reading it because it doesn't match the Arabic reading, but because of my habit I like to see Latin but it's good to help for beginners like us "[27]

transliteration of the Qur'an that did not match her pronunciation because at that time the reading she was reading read not according to reading recitation friends. It was then that Mrs. Endang realized how important it was to learn to read the Al-Qur'an, but after that Mrs. Endang did not want to read the transliteration of the Al-Quran anymore. at this time he only 
reads the translation of the Al-Qur'an alone to avoid mistakes if he reads the transliteration of the Al-Qur'an

2. Solutions to User Problems Al-Qur'an Transliteration

There are 3 solutions provided by the students at the Annaba Center Indonesian Islamic Boarding School as users of the Al-Qur'an Transliteration who have converts to the background. First, that is, it needs proper regulations from the government in this case the Ministry of Religion - Lajnah Pentashihan Al-Qur'an Mushaf. It is hoped that the manuscripts that include transliteration should include a reading guide that also accommodates recitation of tajweed [26].

\section{Conclusion}

Based on the description of the results of the analysis, the author gets an understanding of the definition of transliteration in the Koran according to the students at the Islamic Boarding School for Muallaf Development at the Annaba Center Indonesia Foundation, which is divided into two groups of understanding, namely transliteration of the Qur'an, Arabic-Latin (Indonesian) and transliteration. Al-Qur'an as a tool in reading the Koran. while the view of the transliteration of the Al-Qur'an for santri at the Annaba Center Indonesian Islamic Boarding School, according to the results of the data the author obtained, was divided into 2 groups of views. There are those who think that transliteration of the Al-Quran is easy and others see that transliteration of the Al-Quran is a way to help read the Al-Qur'an.

Judging from the background of the students, who come from converts, of course they have a higher level of difficulty, because they do not know enough Arabic letters, so transliteration becomes their tool for reading the Al-Quran.

Al-Qur'an as a way of life for Muslims turns out to have an impact on anyone who interacts with it, including the transliteration of the Al-Qur'an Mushaf, one of which is the santri at the Annaba Center Indonesia Foundation Muallaf Development Pesantren. Students who are users of the Al-Qur'an Transliteration from among converts get the impact of studying the Al-Qur'an Transliteration, by participating in the recitation of Al-Qur'an reading deposits, it is known that transliteration can spoil the user if it is not accompanied by learning Al-Qur'an reading. Intensive Quran. In practice, users do not really understand transliteration symbols. On the other hand, users are also felt to be minimal in reading information about transliteration and have not tried their best to know and learn more about what and how transliteration is. The intensity of reading the transliterated Al-Qur'an is also lacking, so it requires more intensive assistance. 


\section{References}

[1] "Quran Surat Yusuf Ayat 2 Arab, Latin, Terjemahan Arti Bahasa Indonesia." https://tafsirweb.com/3740-quran-surat-yusuf-ayat-2.html (accessed Dec. 12, 2020).

[2] "Buta Huruf Alquran Di Indonesia - Blog Islamic Pro." https://blog.islamicpro.my.id/butahuruf-alquran-di-indonesia/ (accessed Dec. 12, 2020).

[3] "problematika transliterasi arab latin - Penelusuran Google." https://www.google.com/search?q=problematika+transliterasi+arab+latin\&oq=problematika + tr ansliterasi + arab+latin\&aqs $=$ chrome..69i57.35727j0j4\&sourceid $=$ chrome\&ie $=U T F-8$ (accessed Jan. 18, 2021).

[4] "Kamus besar Bahasa Indonesia / Tim Penyusun Kamus Pusat Pembinaan dan Pengembangan Bahasa $\quad$ OPAC Perpustakaan Nasional RI." https://opac.perpusnas.go.id/DetailOpac.aspx?id=53602 (accessed Dec. 12, 2020).

[5] "pedoman transliterasi kemenag - Penelusuran Google." https://www.google.com/search?safe=strict\&sxsrf=ALeKk02f581DcKsitNsLwDSgXwYCU62 3wg\%3A1610943018086\&ei=KgoFYJrPBJb2rQGXorGgBA\&q=pedoman+transliterasi+keme nag\&oq=pedoman+transliterasi+kemenag\&gs $1 \mathrm{cp}=\mathrm{CgZwc} 3 \mathrm{ktYWIQAzoECCMQJ1CNE} 1 \mathrm{jKI}$ GCEKWgAcAB4AIABowGIAdcJkgEDMi44mAEAoAEBqgEHZ3dzLXdpesABAQ\&sclient= psy-ab\&ved=0ahUKEwiajOKyzqTuAhUWeysKHRdRDEQQ4dUDCAw\&uact=5 (accessed Jan. 18, 2021).

[6] Muhammad Musaddad, “Al-Qur'an Transliterasi Latin dan Problematikanya dalam Masyarakat Muslim Denpasar" Shuhuf, Vol 10, No.1, Juni 2017. .

[7] Nur Fauzan Muhammad, "Problematika Transliterasi Aksara Arab-Latin: Studi Kasus Buku Panduan Manasik Haji dan umrah", NUSA, Vol 12, No 1, Februari 2017. .

[8] Peter Salim, The Contemporary English-Indonesia Dictionary (Jakarta: Modern English Press, 1996), h. 2100.

[9] Barbara Ann Kipfer, Fandom House Webster's College Dictionary (USA: Random House Edition, 2011), h. 1299. .

[10] Noah Webster, Webster's New Twentieth Century Dictionary Of The English Language Unabrigde, (William Collins Publisher INC, 1980), h. 1939.

[11] "Abdul Rasyid, ' Romanisasi Al-Qur'an Transliterasi vs Transkipsi', (Tesis S2 Fakultas Ushuluddin, Institut Ilmu Al-Qur'an Jakarta, 2012), h. 33.”

[12] "Reciprocal relationship between one symptom and another symptom.".

[13] Widodo, Metodologi Penelitian Populer \& Praktis (Jakarta: Rajawali Press, 2017), h. 66-67. .

[14] Marjan Chotib , "Penerapan Tajwid Transliterasi Al-Qur'an (Kajian Komparatif Transliterasi 6 Mushaf Al-Qur'an Kemenag),", h. 24. .

[15] Yusuf Al-Qardawi, Fatwa-fatwa kontemporer. Penerjemah suri sudahri dkk. (Jakarta: Pustaka al-Kautsar, 2009), h. 81.

[16] "Eva Nugraha, 'Konsep al-Nabi al-Ummi dan implikasinya pada penulisan Rasm', Refleksi 13, no. 2 (2012): h. 277."

[17] Badruddin Muhammad bin Abdullah az-Zakarsyā, Al-Burhān fĩ 'ulum Al-Qur'an (Beirut: Dār al-Fikr, 1988), h. 460. .

[18] "Personal interview with Mr. Nababan, living room Pesantren Pembinaan Muallaf Yayasan Annaba Center Indonesia Kampung Sawah Ciputat Tangerang Selatan, 12 October 2019 at 20:01 WIB.".

[19] "Harimurti Kridalaksana, Kamus Linguistik, Edisi IV, (Jakarta: Gramedia, 2008), h. 247.”.

[20] "Personal interview with Mrs. Nuur Hidayah Rumahorbo, Islamic prayer room Pesantren Pembinaan Muallaf Yayasan Annaba Center Indonesia Kampung Sawah Ciputat Tangerang Selatan, 09 October 2019 at 06:20 WIB.”.

[21] Prakata Mushaf Al-Qur'an Transliterasi Per Kata dan Terjemah Per Kata At-Thayyib (Bekasi: Cipta Bagus Segara, 2011). .

[22] Mushaf Al-Qur'an Al-Hadi Mushaf Latin (Jakarta: Maktabah Al-Fatih Rasyid Media, 2015). .

[23] Al-Qur'an Tajwid Warna Transliterasi Per Ayat Terjemah Per Ayat (Al-Munawwar) (Bekasi: Cipta Bagus Segara, 2015). . 
[24] "Personal interview with Amel and Z.A,female room Pesantren Pembinaan Muallaf Yayasan Annaba Center Indonesia Kampung Sawah Ciputat Tangerang Selatan, 13 September 2019 at 14:47 WIB." .

[25] "Personal interview with Sakinatuddiniah, in front of living room Pesantren Pembinaan Muallaf Yayasan Annaba Center Indonesia Kampung Sawah Ciputat Tangerang Selatan, 08 September 2019 at 20:34 WIB."

[26] "Personal interview with Siti Hajar, Mushalla Pesantren Pembinaan Muallaf Yayasan Annaba Center Indonesia Kampung Sawah Ciputat Tangerang Selatan, 09 September 2019 at 20:01 WIB."

[27] "Personal interview with graciella Victoria Safira, Mushalla Pesantren Pembinaan Muallaf Yayasan Annaba Center Indonesia Kampung Sawah Ciputat Tangerang Selatan, 09 September 2019 at 19:22 WIB." 